\title{
Laporan Perancangan Sistem Informasi Penyewaan Kaset VCD/DVD Pada Raisya Rental
}

\author{
Andri Suryadi \\ Fakultas Sains dan Teknologi, Universitas Terbuka \\ andri.suryadi@ecampus.ut.ac.id
}

\begin{abstract}
Abstrak - Berkembangnya kegiatan ekonomi pada saat ini memicu kegiatan ekonomi di semua bidang. Di antara kegiatan ekonomi tersebut adalah kegiatan bisnis di bidang persewaan kaset VCD/DVD, sehingga pada saat ini banyak muncul usaha yang bergerak di bidang persewaan kaset VCD/DVD. Pemanfaatan sistem informasi berbasis komputer dapat membantu proses pengolahan data menjadi lebih cepat dan mudah. Berdasarkan hasil observasi dan wawancara yang dilakukan, diketahui bahwa pada Raisya Rental, semua sistem manajemennya dijalankan secara manual. Adapun kegiatan yang masih berjalan secara manual adalah pengentrian data penyewa dan identitas VCD/DVD, sehingga sering terjadi kesalahan maupun kehilangan data-data secara tidak sengaja, yang mengakibatkan para pemberi jasa mendapatkan kerugian yang cukup besar. Hal ini dapat diatasi dengan pemanfaatan sistem informasi berbasis komputer. Berdasarkan paparan yang telah disimpulkan diperlukan sebuah sistem informasi yang memanfaatkan komputer yang dapat menangani dan mengelola datadata yang berhubungan dengan pengentrian data penyewa dan identitas VCD/DVD. Untuk mendapat informasi yang baik dan akurat, maka diperlukan adanya sistem informasi yang mampu memenuhi kebutuhan pengelolaan data-data penyewaan pada Raisya Rental. Berdasarkan atas gambaran tersebut, maka penulis memilih judul Sistem Informasi Penyewaan Kaset Vcd/Dvd Pada Raisya Rental menggunakan metode prototype.
\end{abstract}

Kata Kunci : Rental, VCD, Sistem Informasi, Prototype

\section{PENDAHULUAN}

Semakin berkembangnya kegiatan ekonomi pada saat ini memicu kegiatan ekonomi di semua bidang. Di antara kegiatan ekonomi tersebut adalah kegiatan bisnis di bidang persewaan kaset VCD/DVD, sehingga pada saat ini banyak muncul usaha yang bergerak di bidang persewaan kaset VCD/DVD. Salah satu perusahaan tersebut adalah Raisya Rental. Sistem informasi berbasis komputer telah banyak diaplikasikan dalam berbagai bidang kehidupan. Pemanfaatan sistem informasi berbasis komputer dapat membantu proses pengolahan data menjadi lebih cepat dan mudah. Berdasarkan hasil observasi dan wawancara yang dilakukan, diketahui bahwa pada Raisya Rental, semua sistem manajemennya dijalankan secara manual. Adapun kegiatan yang masih berjalan secara manual adalah pengentrian data penyewa dan identitas VCD/DVD, sehingga sering terjadi kesalahan maupun kehilangan data-data secara tidak sengaja, yang mengakibatkan para pemberi jasa mendapatkan kerugian yang cukup besar. Hal ini dapat diatasi dengan pemanfaatan sistem informasi berbasis computer [6]. Berdasarkan paparan yang telah disimpulkan diperlukan sebuah sistem informasi yang memanfaatkan komputer yang dapat menangani dan mengelola datadata yang berhubungan dengan pengentrian data penyewa dan identitas VCD/DVD. Diharapkan dengan adanya sistem tersebut, dapat menghindari kesalahan dalam pengelolaan data [7]. Untuk mendapat informasi yang baik dan akurat, maka diperlukan adanya sistem informasi yang mampu memenuhi kebutuhan pengelolaan data-data penyewaan pada Raisya Rental. Berdasarkan atas gambaran tersebut, maka penulis memilih judul Sistem Informasi Penyewaan Kaset Vcd/Dvd Pada Raisya Rental dengan metode prototype [3].

\section{KAJIAN PUSTAKA}

\section{a. Sistem}

Menurut Jogiyanto [2], "Sistem adalah suatu jaringan kerja dari prosedur-prosedur yang saling berhubungan, berkumpul bersama-sama untuk melakukan suatu kegiatan atau untuk menyelesaikan suatu sasaran yang tertentu"

\section{b. Informasi}

Menurut Jogiyanto [2] "Informasi adalah data yang telah diolah menjadi bentuk yang lebih berarti dan berguna bagi penerimanya untuk mengambil keputusan masa kini maupun masa yang akan datang". 


\section{c. UML (Unified Modeling Language)}

Menurut Rosa dan Shalahuddin [1], "UML adalah salah satu satu standar bahasa yang banyak digunakan di dunia industry untuk mendefinisikan requiretment, membuat analisis dan desain, serta menggambarkan arsitektur dalam pemrograman berorientasi objek"

\section{METODE PENELITIAN}

Menurut Pressman [4],dalam melakukan perancangan sistem yang akan dikembangkan dapat menggunakan metode prototype. Metode ini dimulai dengan pengumpulan kebutuhan, kemudian membuat rancangan kilat yang selanjutnya akan dievaluasi kembali sebelum diproduksi secara benar. Adapun Metode pengembangan sistem model Prototype dapat dilihat pada Gambar 1.

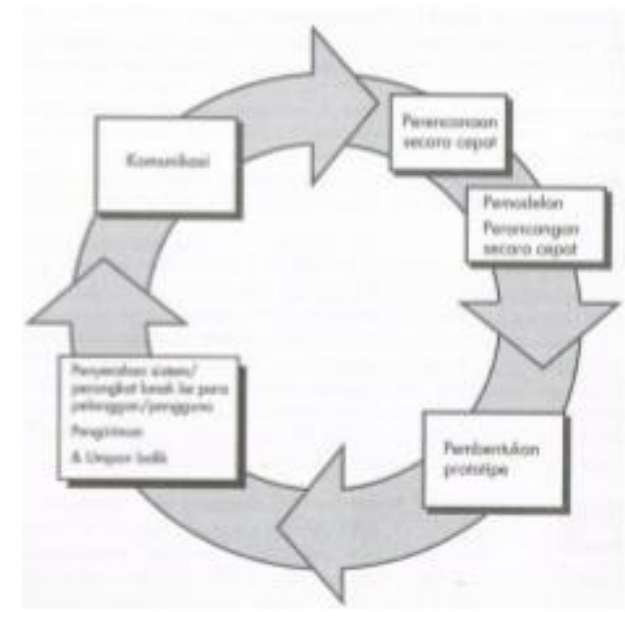

Gambar 1. Prototype Model

Berikut adalah tahapan dalam metode prototype :

1. Komunikasi, yaitu analisis terhadap kebutuhan pengguna. Penulis dan klien bertemu dan menentukan tujuan umum, kebutuhan yang diketahui dan gambaran bagian-bagian yang akan dibutuhkan berikutnya dalam membangun sistem.

2. Perencanaan secara cepat yaitu pembuatan desain secara umum untuk selanjutnya dikembangkan kembali.

3. Pembentukan prototype, yaitu pembuatan perangkat prototype termasuk pengujian dan penyempurnaan.

4. Evaluasi terhadap prototype, yaitu mengevaluasi prototype dan memperhalus analisis terhadap kebutuhan pengguna.

5. Perbaikan prototype, yaitu pembuatan tipe yang sebenarnya berdasarkan hasil dari evaluasi prototype.
6. Produksi akhir, yaitu memproduksi perangkat secara benar sehingga dapat digunakan oleh pengguna.

\section{PEMBAHASAN DAN HASIL}

\section{PENELITIAN}

\section{a. Manual Sistem}

Sistem peminjaman cd/dvd yang sedang berjalan (Current system) saat ini yaitu user (Pelanggan) pergi ke Raisya Rental, ketika ingin meminjam CD/DVD tujuan utamanya adalah pergi ke sistem informasi CD/DVD yang ada di Raisya Rental untuk memastikan ketersediaan CD/DVD yang dimaksud, ketika CD/DVDnya tersedia sistem informasi tersebut akan memberikan informasi yang dibutuhkan user (Pelanggan), setelah itu user akan ke lokasi CD/DVD yang hendak dipinjam, setelah mendapatkan CD/DVD tersebut user akan berhubungan kepada petugas Raisya Rental untuk menyelesaikan administrasi peminjaman.

Kelemahan pada sistem ini adalah hanya berjalan secara manual, artinya kegiatan atau proses pencarian informasi CD/DVD serta peminjaman hanya dapat dilakukan pada saat user berada diRaisya Rental, dan mungkin bagi orang-orang yang sibuk dan tidak sempat keRaisya Rental malas untuk melakukan kegiatan seperti yang terurai di atas apalagi kita dapat lihat betapa luasnya Raisya Rental saat ini, sehingga mereka lebih memilih tidak melakukan kegiatan tersebut kecuali terdesak.

\section{b. Sistem Yang Diusulkan (Proposed System)}

Seperti yang terurai pada current system di atas bahwa kelemahan sistem saat ini adalah hanya dapat dilakukan secara manual sehingga membuat hampir sebagian Pelanggan (user) menjadi malas, maka dari itu untuk menjawab kelemahan sistem maka solusi sistem yang saya akan usulkan yaitu kegiatan peminjaman dilakukan secara online. Perhatikan gambar di bawah ini.

Deskripsi peminjaman cd/dvd berdasarkan proposed system.

1. Pelanggan membuka situs Raisya Rental online yang tersedia, kemudian Login dengan memasukkan Nim dan password, setelah masuk ke situs maka anggota dipersilahkan mengecek ketersediaan CD/DVD dengan 
memasukkan judul Judul Film / Tahun rilis / Kode CD/DVD

2. Ketika Film pada CD/DVD ditersedia, maka anggota bisa membooking melalui situs dan kode booking akan tercetak beserta bukti peminjaman dari situs. Kode booking berlaku selama 2 hari dari jadwal pembookingan.

3. Anggota ke Raisya Rental untuk mengambil CD/DVD yang telah di booking dengan menyerahkan kode booking kepada petugas Raisya Rental.

4. Petugas Raisya Rental mengecek kemudian memberikan Film dalam bentuk CD/DVD yang akan dipinjam beserta bukti peminjaman dari Raisya Rental.

\section{c. Analisi Kebutuhan Sistem (Requirement System) SRS (Software Requirement Specificatin)}

\section{Kebutuhan Fungsional}

Kebutuhan fungsionalitas merupakan kebutuhan utama yang berkaitan langsung dengan pelayanan aplikasi Sistem Informasi penyewaan VCD/DVD yang meliputi dibagi menjadi beberapa modul seperti yang tercantum dalam tabel di bawah ini:

1. Login dan user name

2. Input dan simpan data pelanggan

3. Input dan simpan data sewa

4. Input dan simpan data kembali

5. Input dan simpan film baru

6. Tambah stok film lama dan simpan

\section{Kebutuhan data}

1) Data anggota.

2) Data CD/DVD.

3) Data peminjaman

Kebutuhan Teknologi

1) Internet berbasis web

Kebutuhan NonFungsional

1) Perangkat computer.

2) Peralatan input dan ouput data.

3) Browser internet.

4) System operasi.

5) PHP Triad (Apache, PHP, dan My SQL)

6) Aplikasi web desain

\subsection{Use Case Diagram}

\section{Case Administrator}

3.4.1. Case Akses

1) Case Akses Petugas dan Pengunjung

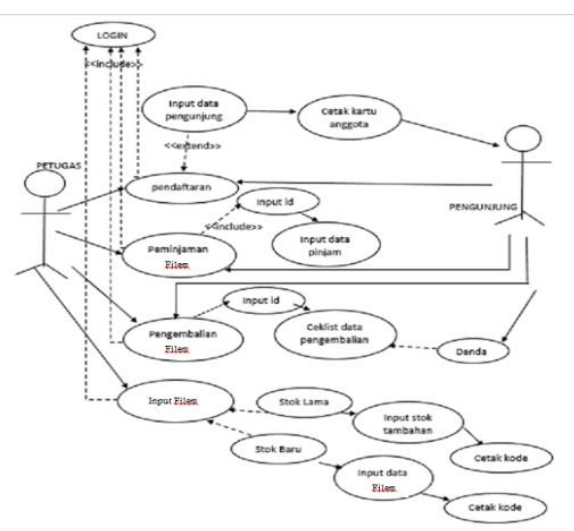

Gambar 1 Diagram Use Case Petugas dan pengunjung

Case Login

- Tujuan : Menampilkan halaman login.

- Actor : Petugas.

- Use Case : Sistem akan menampilkan halaman login dan melakukan dan fitur authentikasi dan otorisasi username dan password terhadap hak akses yang dimiliki user.

\section{Case Pendaftaran}

- Tujuan : Mengelola data pendaftaran anggota baru.

- Actor : Petugas dan pengunjung

- Use Case : Sistem akan menyimpan inputan data aggota baru, dan mencetak kartu anggota

\section{Case Peminjaman Film}

- Tujuan : Mengelola data peminjaman Film.

- Actor : Petugas dan pengunjung.

- Use Case : Sistem akan menyimpan data peminjaman Film

\section{Case pengembalian Film}

- Tujuan : Mengelola data pengembalian Film.

- Actor : Petugas dan pengunjung.

- Use Case : Sistem akan meyimpan data pengembalian Film berupa ceklist pada tangga tempo pengembalian Film di daata peminjamaan Film. 


\section{Case Input Film}

- Tujuan : Untuk menginputkan Film baru atau Film tambahan stok lama.

- Actor : Petugas.

- Use Case : Petugas akan menginput Film baru atau menmbah stok Film lama dan sistem akan menyimpannya.

\section{Use Case Akses Administrator}

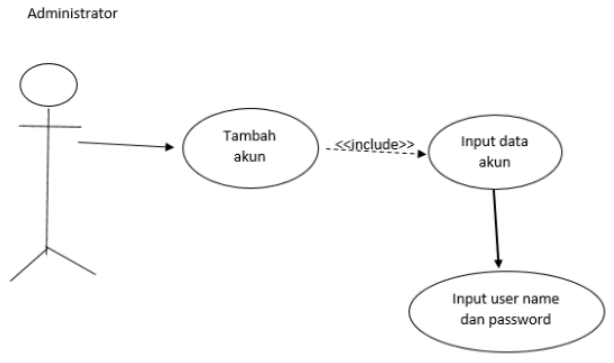

Gambar 3. 2 Use Case Akses Administrator

\section{Case Tambah akun}

- Tujuan : Mendaftarkan nama-nama akun, bagi yang diberi hak akses

- Actor : Administrator

- Use Case : Administrator mendaftarkan nama yang diberi hak aksse, dan menginput data, sistem akan menyimpannya, dan adminisrator menginput username, passwordnya akun baru.

\section{Activity Diagram sistem Film}

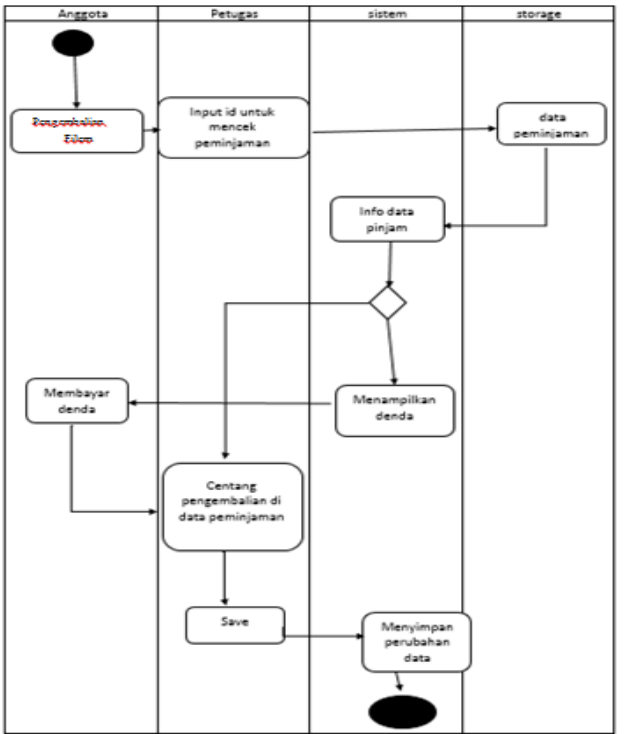

Gambar 3. 3 Activity system Penyewaan VCD/DVD

\subsection{Sistem yang Telah Dibuat}

3.3.1 Login
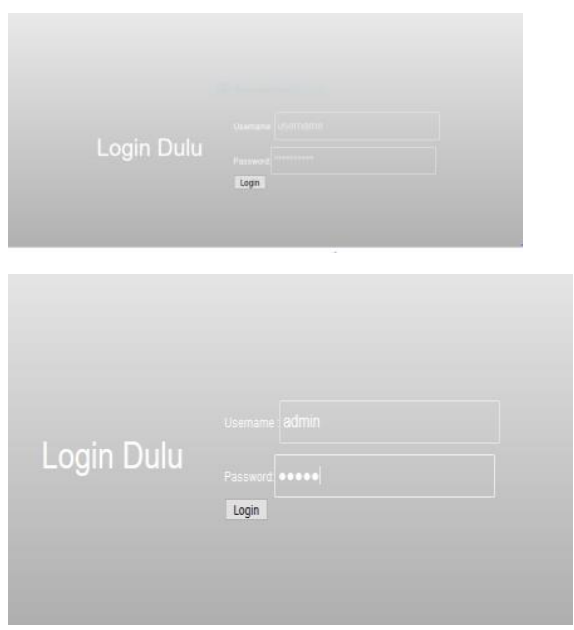

\subsubsection{Menu Utama}

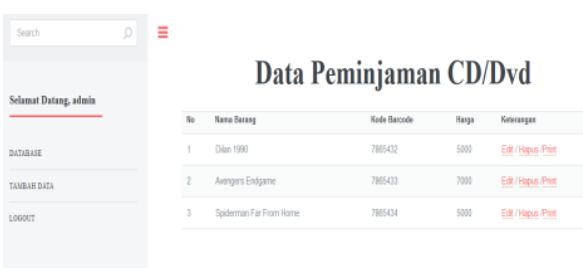




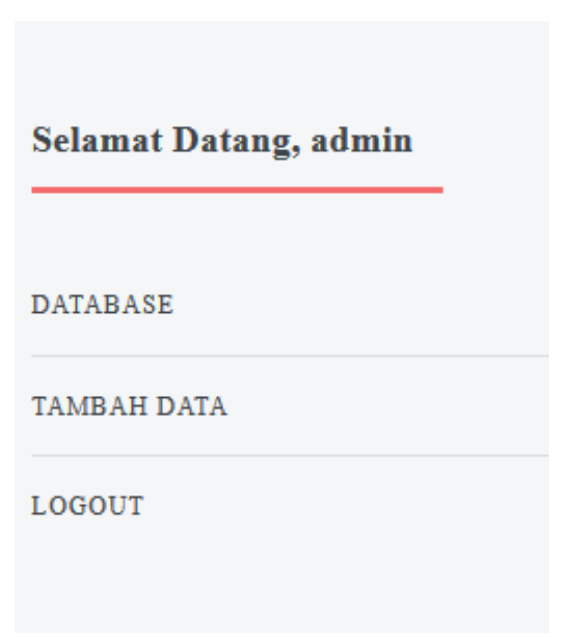

4

\section{Data CD/DVD}

$\equiv$

Data Peminjaman CD/Dvd

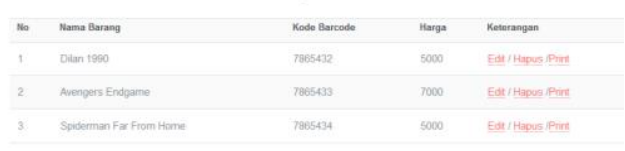

5

Input CD/DVD

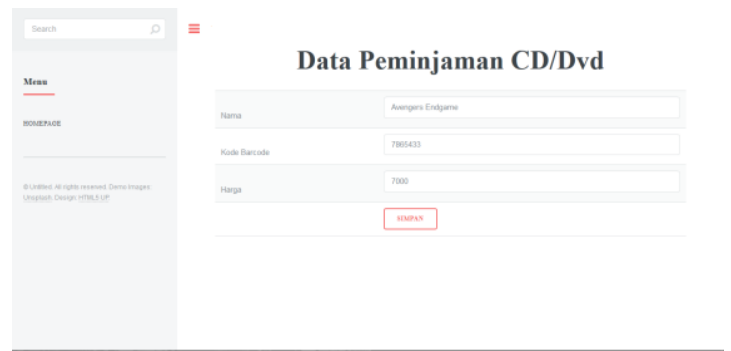

\section{Kelebihan dan Kekurangan}

3.6.1. Kelebihan

1) Tidak terbatas dengan ruang yang ada.

2) Anggota tidak perlu capek-capek datang ke Raisya Rental untuk memeriksa CD/DVD yang tersedia.

3) Menghemat ruangan

4) Pendekatan berstruktur dan lebih akurat dalam hal pencarian.

\subsubsection{Kekurangan}

1) Pengguna masih banyak yang lebih menyukai membaca teks tercetak dibandingkan teks digital.
2) Masih belum tersedianya CD/DVD digital.

3) Pada pengisian menu transaksi masih banyak memakan waktu dan proses yang cukup rumit.

4) Warna dari font pada header terlalu gelap sehingga sulit untuk membacanya.

5) Masih berbasis desktop dan belum online

\section{Kesimpulan}

Sistem informasi Raisya Rental merupakan suatu sistem pengolahan data yang memanfaatkan teknologi komputerisasi berupa sistem Raisya Rental yang di bangun dari hasil analisis pada Raisya Rental . Berikut kesimpulan yang didapat dari proses analisis, perancangan dan implementasi sistem:

1) Diharapkan aplikasi Raisya Rental ini dapat membantu kegiatan pendaftaran lebih efektif dan efisien sehingga tidak memakan waktu dalam proses pendaftaran.

2) Diharapkan aplikasi Raisya Rental dapat membantu penyimpanan data peminjaman dan pengembalian sehingga meminimalisir kehilangan maupun kerusakan dokumen.

3) Diharapkan dapat menghitung denda keterlambatan secara akurat.

4) Diharapkan pada proses pencatatan laporan data CD/DVD, anggota, peminjaman maupun pengembalian CD/DVD di Raisya Rental dapat lebih memudahkan dalam pembuatan laporan dan meminimalisir kesalahan data.

\section{Saran}

Penulis berharap agar informasi yang telah disampaikan dapat berguna bagi Petugas Raisya Rental Garut dan aplikasi yang telah dibuat dapat membantu dalam proses pendaftaran peminjaman dan pengembalian CD/DVD sesuai dengan yang diharapkan. Adapun saran terhadap penggunaan sistem yang telah dibuat adalah sebagai berikut :

1) Bagi peneliti lain yang meneliti sistem informasi Raisya Rental diharapkan dapat mengembangkan aplikasi tersebut dengan mendata semua peminjaman CD/DVD.

2) Bagi peneliti lain diharapkan dapat menambahkan Pelanggan yang meminjam dapat login dan meng inputkan peminjaman. 
3) Bagi peneliti lain yang meneliti sistem informasi Raisya Rental diharapkan dapat menambahkan proses kehilangan $\mathrm{CD} / \mathrm{DVD}$

\section{DAFTAR PUSTAKA}

[1] A. S., Rosa dan Shalahuddin, M. 2013. Rekayasa Perangkat Lunak Terstruktur Dan Berorientasi Objek. Informatika. Bandung.

[2] Jogiyanto H.M. (2005:1), Analisis dan Desain Informasi, Andi. Yogyakarta.

[3] Lestariningsih, Tri. "Analisis Sitem Informasi Dalam Perspektif Human Computer Interaction." Jurnal AKSI (Akuntansi dan Sistem Informasi) 1.1 (2016): 5-9.

[4] Pradipta, Afghan Amar, Yuli Adam Prasetyo, and Nia Ambarsari. "Pengembangan Web E-Commerce Bojana Sari Menggunakan Metode Prototype." eProceedings of Engineering 2.1 (2015).

[5] Roger, S. Pressman, Ph.D. , 2012, Rekayasa Perangkat Lunak (Pendekatan Praktisi) Edisi 7 : Buku 1 “, Yogyakarta: Andi.

[6] Suryadi, Andri, Erwin Harahap, and Adi Rachmanto. "Rancang Bangun Sistem Infromasi Persediaan Obat Berbasis Web Di Apotek XYZ." Jurnal PETIK 4.2 (2018): 114-119.

[7] Suryadi, Andri. "Perancangan Aplikasi Game Edukasi Menggunakan Model Waterfall." Jurnal PETIK 3.1 (2017): 8-13. 